\title{
Evaluation of Indonesian National Qualification Framework-Based Learning Process in Faculty of Education Universitas Negeri Yogyakarta
}

\author{
Wahyuningrum \\ Department of Educational Management \\ Universitas Negeri Yogyakarta \\ Yogyakarta, Indonesia \\ wahyuningrum@uny.ac.id
}

\begin{abstract}
The aim of this study was to find out the success of Indonesian National Qualification Framework-based learning process in Faculty of Education, Universitas Negeri Yogyakarta (Yogyakarta State University). Indonesian National Qualification Framework-based learning process is said to be successful if it is appropriate with the quality standard of Indonesian National Qualification Frameworkbased curriculum. This study was designed as evaluation research with quantitative approach. The data of this research was collected by using instrument in the form of questionnaires. The subjects of this research were lecturers of Faculty of Education, Universitas Negeri Yogyakarta. The populations were 164 lecturers from 9 departments. The sample was got by using proportional random sampling technique. From each department, $25 \%$ of lecturers were taken as sample and therefore there were 43 lecturers in total. The data was analysed by employing descriptive quantitative technique. The result of this research showed that: (1) The success of Indonesian National Qualification Framework-based learning process was categorized as very good and the percentage was $92.35 \%$, (2) The success of Indonesian National Qualification Framework-based learning process which was observed from curriculum development aspect was categorized as very good and its percentage was $96.71 \%$, and (3) The success of Indonesian National Qualification Framework-based learning process which was observed from learning process aspect was categorized as very good and its percentage was 95.19\%.
\end{abstract}

Keywords-Learning evaluation, Indonesian National Qualification Framework-based learning process

\section{INTRODUCTION}

As the challenge in education field changes, curriculum in college always changes too. The change of curriculum as follow-up to evaluation is intended to improve the education quality. The newest curriculum has been established by the government through Peraturan Menteri Pendidikan dan Kebudayaan Republik Indonesia Nomor 73 Tahun 2013 concerning Penerapan Kerangka Kualifikasi Nasional
Indonesia Bidang Pendidikan. Furthermore, in verse (1) of article 2, it is explained that Indonesian National Qualification Framework(Kerangka Kualifikasi Nasional Indonesia/Indonesian National Qualification Framework) in college field is aframework of qualification stage which can put together, parallel, and integrate learning achievement from informal education, formal education, and/or working experience into kinds and level of college education [1]. Indonesian National Qualification Framework gives measurement parameter in the form of qualification. Learning achievement is achieved through internalization of knowledge, behaviour, skill, competence, and the accumulation of working experience.

Evaluation needs to be conducted to figure out whether the learning process is said to be effective and efficient and can achieve its goal. Evaluation is a process or activities of selecting, collecting, analysing, and presenting information which can be used as a base to make decision and arrange the following program. It is important to conduct evaluation as feedback for the previous learning process. Evaluation can also give information which is necessary for conducting the next learning process (feedforward).

Evaluation is conducted to improve the quality and the standard of learning process. Learning process in FIP UNY has not been conducted completely well. Each change needs adaptation. So does the implementation of new Indonesian National Qualification Framework-based curriculum. Often, curriculum has changed but the educators/lecturer still use old curriculum. Even though learning kits such as RPS has been adjusted to suit the change, the method and strategy which are used still refer to habit of old teaching process. Strategy and method of learning process also tend to be teacher-centered learning (TCL).

Indonesian National Qualification Framework-based curriculum demands that learning process is conducted according to Semester Learning Plan (RencanaPembelajaran 
Semester/RPS). Ideally, the lecturer should conduct learning process by implementing student-centered learning (SCL) strategy. SCL is a strategy which positions students as active subjects which are responsible in learning process.

The problems mentioned above got attention in the level of study program, faculty, and even university. Faculty and lecturers work together to guarantee that Indonesian National Qualification Framework standard can be achieved. They work on learning process, learning strategy, exam mechanism, and standardization in arranging questions of final semester test. Based on the explanation above, it can be concluded that it needs to conduct a research which focuses on The Evaluation of Indonesian National Qualification Framework-based Learning Process in Faculty of Education Science of Universitas Negeri Yogyakarta. The statement of problem of this research was: To what extent the success of learning process which is based on standard of Indonesian National Qualification Framework-based learning process in Faculty of Education Science of Universitas Negeri Yogyakarta? This purpose of this research was to figure out the success of learning process which is based on standard of Indonesian National Qualification Framework-based learning process in Faculty of Education Science.

\section{METHODS}

\section{Research Approach}

This research was evaluation research with quantitative approach. The research was conducted by employing open questionnaire and closed questionnaire. The data from closed questionnaire was presented in quantitative form, whereas the data from open questionnaire was presented in descriptive-qualitative form.

\section{The population and sample of the research}

The subjects of this research were lecturers of FIP UNY who gave lecture in even semesters (second semester and fourth semester) and odd semesters (first, third, and fifth semesters) in academic year 2014/2015 and 2015/2016. The number of population was 164 . Sampling technique which was employed was proportional random sampling technique. $25 \%$ of lecturers was taken from each study program and therefore there were 43 lecturers in total. The following table shows the population and sample.
Table 1. The Number of Population and Sample of The Research

\begin{tabular}{|c|c|c|c|}
\hline No & Study Program & Population & Sample \\
\hline 1. & $\begin{array}{l}\text { Manajemen } \\
\text { Pendidikan/Educatonal } \\
\text { Management(MP) }\end{array}$ & 20 & 5 \\
\hline 2. & $\begin{array}{l}\text { Pendidikan Luar } \\
\text { Sekolah/Nonformal } \\
\text { Education (PLS) }\end{array}$ & 15 & 4 \\
\hline 3. & $\begin{array}{l}\text { Pendidikan Luar } \\
\text { Biasa/Special Needs } \\
\text { Education (PLB) }\end{array}$ & 20 & 5 \\
\hline 4. & $\begin{array}{l}\text { Bimbingan dan } \\
\text { Konseling/Guidance and } \\
\text { Counseling (BK) }\end{array}$ & 18 & 5 \\
\hline 5. & $\begin{array}{l}\text { Teknologi } \\
\text { Pendidikan/Educational } \\
\text { Technology (TP) }\end{array}$ & 18 & 5 \\
\hline 6. & $\begin{array}{l}\text { Pendidikan Guru Sekolah } \\
\text { Dasar/Primary Teacher } \\
\text { Education (PGSD) }\end{array}$ & 38 & 10 \\
\hline 7. & $\begin{array}{l}\text { Kebijakan } \\
\text { Pendidikan/Educational } \\
\text { Policy (KP) }\end{array}$ & 15 & 4 \\
\hline 8. & $\begin{array}{l}\text { Pendidikan Guru } \\
\text { Pendidikan Anak Usia } \\
\text { Dini/Early Childhood } \\
\text { Teacher Education } \\
\text { (PGPAUD) }\end{array}$ & 12 & 3 \\
\hline 9. & Psikologi/Psychology (P) & 8 & 2 \\
\hline & Total & 164 & 43 \\
\hline
\end{tabular}

\section{Data Collecting Technique}

The data of this research was collected by employing questionnaire concerning learning process and documentation study at Faculty of Education Science of UniversitasNegeri Yogyakarta.

\section{Data Analysis Technique}

The technique of data analysis was quantitative descriptive with percentage. According to SuharsimiArikunto (2010: 269), there are five categories in quantitative data analysis. These five categories are as follows: 
Table 2. The Categories Percentage of the Success of Indonesian National Qualification Framework-based Learning Process

\begin{tabular}{|c|c|c|}
\hline No & Interval & Category \\
\hline 1 & $100 \%$ & Very good \\
\hline 2 & $61-80 \%$ & Good \\
\hline 3 & $41-60 \%$ & Moderate \\
\hline 4 & $21-40 \%$ & Less good \\
\hline 5 & $0-20 \%$ & Not good \\
\hline
\end{tabular}

\section{Research Instrument}

The instrument of this research was arranged by using questionnaire. The learning process which was evaluated referred to the standard of Indonesian National Qualification Framework-based learning process. The standard of learning process was observed from 3 sub-variables. These subvariables are graduate's competence, curriculum development, and learning process. The questionnaire consisted of 81 items of closed question with the options of the answer were "Yes" and "No". The questionnaire also contained column where samples could give written feedback/opinion/information.

\section{RESULT AND DISCUSSION}

\section{The Result of The Research}

This research dealt with the success of Indonesian National Qualification Framework-based learning process in Faculty of Science Education in nine study programs. These study programs were Manajemen Pendidikan, Pendidikan Luar Sekolah, Pendidikan Luar Biasa, Bimbingan dan Konseling, Teknologi Pendidikan, Pendidikan Guru Sekolah Dasar, Kebijakan Pendidikan, Pendidikan Guru PAUD, and Psikologi. The success of this learning process observed RPS (Rencana Pembelajaran Semester/Semester Learning Plan), lecture execution, and graduate's competence.

The research of the success of Indonesian National Qualification Framework-based learning process was conducted upon theoretical college lecture on even semesters (second semester and fourth semester) and odd semesters (first, third, and fifth semester) of nine study programs in FIP UNY. The aspect of graduate's competence dealt with cognitive competence mastery, affective competence mastery (attitude and mark), and psychomotor competence mastery (skill). Curriculum aspect discussed the arrangement of content and curriculum development.
Learning process aspect concerned preparation, execution, supervision, learning evaluation, guidance in final project, graduate's competence, curriculum, and learning process.

The documentation of RPS standard from Indonesian National Qualification Framework-based curriculum was then presented. This RPS contained study program identity, learning target, related study material, final skill, learning method, the given time, learning experience, scoring, and references which were used. The result of the research showed that all lecturers had made learning preparation in the form of RPS. This RPS used the standard of Indonesian National Qualification Framework-based curriculum which consisted of nine components. The lecturers had also considered the relation and cohesiveness of materials, feedback, and follow-up.

The following tables show the result of the research.

Table 3. The Success of Indonesian National Qualification Framework-based Learning Process in FIP

\begin{tabular}{|c|l|c|c|}
\hline \multirow{2}{*}{ No } & \multicolumn{2}{|c|}{ Sub-variable } & \multicolumn{2}{c|}{ Answer Option (\%) } \\
\cline { 3 - 4 } & & Yes & No \\
\hline 1 & Graduate's Competence & 85,15 & 14,85 \\
\hline 2 & Curriculum Development & 96,71 & 3,29 \\
\hline 3 & Learning Process & 95,19 & 4,81 \\
\hline \multicolumn{2}{|c|}{ Mean } & 92,35 & 7,65 \\
\hline
\end{tabular}

Table 4. The Success of Indonesian National Qualification Framework-based Learning Process Observed from Graduate's Competence Aspect

\begin{tabular}{|c|c|c|c|c|c|c|c|c|c|}
\hline \multirow{3}{*}{$\begin{array}{l}\mathrm{N} \\
\mathrm{o}\end{array}$} & \multirow{3}{*}{$\begin{array}{c}\text { Study } \\
\text { Progra } \\
\text { m }\end{array}$} & \multicolumn{2}{|c|}{ Cognitive } & \multicolumn{2}{|c|}{ Affective } & \multicolumn{2}{|c|}{$\begin{array}{l}\text { Psychomot } \\
\text { or }\end{array}$} & \multicolumn{2}{|c|}{ Mean } \\
\hline & & Yes & $\begin{array}{l}\mathrm{N} \\
\mathrm{o}\end{array}$ & Yes & No & Yes & No & Yes & No \\
\hline & & $\%$ & $\%$ & $\%$ & $\%$ & $\%$ & $\%$ & $\%$ & $\%$ \\
\hline 1 & MP & 100 & 0 & $\begin{array}{c}100, \\
00\end{array}$ & 0,00 & $\begin{array}{c}94,2 \\
9\end{array}$ & 5,71 & $\begin{array}{c}98,1 \\
0\end{array}$ & 1,90 \\
\hline 2 & PLS & 87 & 13 & 79 & 20 & $\begin{array}{c}46,4 \\
3\end{array}$ & $\begin{array}{c}53,5 \\
7\end{array}$ & $\begin{array}{c}71,0 \\
3\end{array}$ & $\begin{array}{c}28,9 \\
7\end{array}$ \\
\hline 3 & PLB & 95 & 5 & 87 & $\begin{array}{c}13,3 \\
3\end{array}$ & $\begin{array}{c}71,4 \\
3\end{array}$ & $\begin{array}{c}28,5 \\
7\end{array}$ & $\begin{array}{c}84,3 \\
7\end{array}$ & $\begin{array}{c}15,6 \\
3\end{array}$ \\
\hline 4 & BK & 86 & 15 & 90 & $\begin{array}{c}10,0 \\
0\end{array}$ & $\begin{array}{c}74,2 \\
9\end{array}$ & $\begin{array}{c}25,7 \\
1\end{array}$ & $\begin{array}{c}83,1 \\
0\end{array}$ & $\begin{array}{c}16,9 \\
0\end{array}$ \\
\hline 5 & TP & 90 & 10 & 87 & $\begin{array}{c}13,3 \\
3\end{array}$ & $\begin{array}{c}62,8 \\
6\end{array}$ & $\begin{array}{c}37,1 \\
4\end{array}$ & $\begin{array}{c}79,8 \\
4\end{array}$ & $\begin{array}{c}20,1 \\
6\end{array}$ \\
\hline 6 & PGSD & 95 & 5 & 89 & $\begin{array}{c}10,8 \\
3\end{array}$ & $\begin{array}{c}75,7 \\
1\end{array}$ & $\begin{array}{c}24,2 \\
9\end{array}$ & $\begin{array}{c}86,6 \\
3\end{array}$ & $\begin{array}{c}13,3 \\
7\end{array}$ \\
\hline 7 & KP & $\begin{array}{c}100, \\
0\end{array}$ & 0 & 85 & 15 & $\begin{array}{c}60,7 \\
1\end{array}$ & $\begin{array}{c}39,2 \\
9\end{array}$ & $\begin{array}{c}82,0 \\
4\end{array}$ & $\begin{array}{c}17,9 \\
6\end{array}$ \\
\hline
\end{tabular}


Table 4, Cont.

\begin{tabular}{|l|l|c|c|c|c|c|c|c|c|}
8 & $\begin{array}{l}\text { PG } \\
\text { PAU } \\
\text { D }\end{array}$ & 100 & 0 & 89 & 11,1 & $\begin{array}{c}61,9 \\
0\end{array}$ & $\begin{array}{c}38,1 \\
0\end{array}$ & $\begin{array}{c}83,6 \\
0\end{array}$ & $\begin{array}{c}16,4 \\
0\end{array}$ \\
\hline 9 & $\mathrm{P}$ & 100 & 0 & 100 & 0 & $\begin{array}{c}92,8 \\
6\end{array}$ & 7,14 & $\begin{array}{c}97,6 \\
2\end{array}$ & 2,38 \\
\hline & $\begin{array}{l}\text { Mea } \\
\mathrm{n}\end{array}$ & $\begin{array}{c}94,7 \\
2\end{array}$ & $\begin{array}{c}5,2 \\
8\end{array}$ & $\begin{array}{c}89,5 \\
5\end{array}$ & $\begin{array}{c}10,4 \\
5\end{array}$ & $\begin{array}{c}71,1 \\
6\end{array}$ & $\begin{array}{c}28,8 \\
4\end{array}$ & $\begin{array}{c}85,1 \\
5\end{array}$ & $\begin{array}{c}14,8 \\
5\end{array}$ \\
\hline
\end{tabular}

Table 5. The Success of Indonesian National Qualification Framework-based Learning Process Observed from Curriculum Development Aspect

\begin{tabular}{|c|c|c|c|c|c|c|c|c|c|}
\hline \multirow{3}{*}{$\frac{\mathrm{N}}{\mathrm{o}}$} & \multirow{3}{*}{$\frac{\text { Study }}{\text { Program }}$} & \multicolumn{2}{|c|}{$\begin{array}{l}\text { Curriculum } \\
\text { Arrangeme } \\
\text { nt }\end{array}$} & \multicolumn{2}{|c|}{$\begin{array}{c}\text { Curriculum } \\
\text { Content }\end{array}$} & \multicolumn{2}{|c|}{$\begin{array}{c}\text { Curriculum } \\
\text { Developme } \\
\text { nt }\end{array}$} & \multicolumn{2}{|c|}{ Mean } \\
\hline & & Yes & No & Yes & No & Yes & No & Yes & No \\
\hline & & $\%$ & $\%$ & $\%$ & $\%$ & $\%$ & $\%$ & $\%$ & $\%$ \\
\hline 1 & MP & $\begin{array}{c}91,6 \\
7\end{array}$ & $\begin{array}{c}8,3 \\
3\end{array}$ & $\begin{array}{c}100 \\
00\end{array}$ & $\begin{array}{c}0,0 \\
0\end{array}$ & $\begin{array}{c}100, \\
00\end{array}$ & $\begin{array}{c}0,0 \\
0\end{array}$ & $\begin{array}{c}97,2 \\
2\end{array}$ & $\begin{array}{c}2,7 \\
8\end{array}$ \\
\hline 2 & PLS & $\begin{array}{c}95,8 \\
3\end{array}$ & $\begin{array}{c}4,1 \\
7\end{array}$ & $\begin{array}{c}100 \\
00\end{array}$ & $\begin{array}{c}0,0 \\
0\end{array}$ & $\begin{array}{c}100, \\
00\end{array}$ & $\begin{array}{c}0,0 \\
0\end{array}$ & $\begin{array}{c}98,6 \\
1\end{array}$ & $\begin{array}{c}1,3 \\
9\end{array}$ \\
\hline 3 & PLB & $\begin{array}{c}98,3 \\
3\end{array}$ & $\begin{array}{c}1,6 \\
7\end{array}$ & $\begin{array}{c}100 \\
00\end{array}$ & $\begin{array}{c}0,0 \\
0\end{array}$ & $\begin{array}{c}100, \\
00\end{array}$ & $\begin{array}{c}0,0 \\
0\end{array}$ & $\begin{array}{c}99,4 \\
4\end{array}$ & $\begin{array}{c}0,5 \\
6\end{array}$ \\
\hline 4 & BK & $\begin{array}{c}95,0 \\
0\end{array}$ & $\begin{array}{c}5,0 \\
0\end{array}$ & $\begin{array}{c}100 \\
00\end{array}$ & $\begin{array}{c}0,0 \\
0\end{array}$ & $\begin{array}{c}100, \\
00\end{array}$ & $\begin{array}{c}0,0 \\
0\end{array}$ & $\begin{array}{c}98,3 \\
3\end{array}$ & $\begin{array}{c}1,6 \\
7\end{array}$ \\
\hline 5 & TP & $\begin{array}{c}100 \\
00\end{array}$ & $\begin{array}{c}0,0 \\
0\end{array}$ & $\begin{array}{c}100 \\
00\end{array}$ & $\begin{array}{c}0,0 \\
0\end{array}$ & $\begin{array}{c}100, \\
00\end{array}$ & $\begin{array}{c}0,0 \\
0\end{array}$ & $\begin{array}{c}100, \\
00\end{array}$ & $\begin{array}{c}0,0 \\
0\end{array}$ \\
\hline 6 & PGSD & $\begin{array}{c}96,6 \\
7\end{array}$ & $\begin{array}{c}3,3 \\
3\end{array}$ & $\begin{array}{c}98,3 \\
3\end{array}$ & $\begin{array}{c}1,6 \\
7\end{array}$ & $\begin{array}{c}95,0 \\
0\end{array}$ & $\begin{array}{c}5,0 \\
0\end{array}$ & $\begin{array}{c}96,6 \\
7\end{array}$ & $\begin{array}{c}3,3 \\
3\end{array}$ \\
\hline 7 & KP & $\begin{array}{c}95,8 \\
3\end{array}$ & $\begin{array}{c}4,1 \\
7\end{array}$ & $\begin{array}{c}83,3 \\
3\end{array}$ & $\begin{array}{l}16, \\
67\end{array}$ & $\begin{array}{c}100, \\
00\end{array}$ & $\begin{array}{c}0,0 \\
0\end{array}$ & $\begin{array}{c}93,0 \\
6\end{array}$ & $\begin{array}{c}6,9 \\
4\end{array}$ \\
\hline 8 & $\begin{array}{l}\text { PG } \\
\text { PAUD }\end{array}$ & $\begin{array}{c}83,3 \\
3\end{array}$ & $\begin{array}{l}16, \\
67\end{array}$ & $\begin{array}{c}94,4 \\
4\end{array}$ & $\begin{array}{c}5,5 \\
6\end{array}$ & $\begin{array}{c}83,3 \\
3\end{array}$ & $\begin{array}{l}16, \\
67\end{array}$ & $\begin{array}{c}87,0 \\
4\end{array}$ & $\begin{array}{l}12, \\
96\end{array}$ \\
\hline 9 & $\mathrm{P}$ & $\begin{array}{c}100 \\
00\end{array}$ & $\begin{array}{c}0,0 \\
0\end{array}$ & $\begin{array}{c}100 \\
00\end{array}$ & $\begin{array}{c}0,0 \\
0\end{array}$ & $\begin{array}{c}100, \\
00\end{array}$ & $\begin{array}{c}0,0 \\
0\end{array}$ & $\begin{array}{c}100, \\
00\end{array}$ & $\begin{array}{c}0,0 \\
0\end{array}$ \\
\hline & Mean & $\begin{array}{c}95,1 \\
9\end{array}$ & $\begin{array}{c}4,8 \\
1\end{array}$ & $\begin{array}{c}97,3 \\
5\end{array}$ & $\begin{array}{c}2,6 \\
5\end{array}$ & $\begin{array}{c}97,5 \\
9\end{array}$ & $\begin{array}{c}2,4 \\
1\end{array}$ & $\begin{array}{c}96,7 \\
1\end{array}$ & $\begin{array}{c}3,2 \\
9\end{array}$ \\
\hline
\end{tabular}

Table 6. The Success of Indonesian National Qualification Framework-based Learning Process Observed from Learning Process Aspect

\begin{tabular}{|c|c|c|c|c|c|c|c|c|c|c|c|c|c|}
\hline \multirow{3}{*}{$\begin{array}{l}\mathrm{N} \\
\mathrm{o}\end{array}$} & \multirow{3}{*}{$\begin{array}{c}\text { Stu } \\
\text { dy } \\
\text { Pro } \\
\text { gra } \\
\text { m }\end{array}$} & \multicolumn{2}{|c|}{$\begin{array}{l}\text { Prepa } \\
\text { ration }\end{array}$} & \multicolumn{2}{|c|}{$\begin{array}{c}\text { Executi } \\
\text { on }\end{array}$} & \multicolumn{2}{|c|}{$\begin{array}{l}\text { Superv } \\
\text { ision }\end{array}$} & \multicolumn{2}{|c|}{$\begin{array}{c}\text { Evalua } \\
\text { tion }\end{array}$} & \multicolumn{2}{|c|}{$\begin{array}{l}\text { Final } \\
\text { Project } \\
\text { Guida } \\
\text { nce }\end{array}$} & \multicolumn{2}{|c|}{ Mean } \\
\hline & & $\begin{array}{l}\text { Y } \\
\text { e } \\
\text { s }\end{array}$ & $\begin{array}{l}\mathrm{N} \\
\mathrm{o}\end{array}$ & $\begin{array}{l}\text { Y } \\
\text { es }\end{array}$ & $\begin{array}{l}\mathrm{N} \\
\mathrm{o}\end{array}$ & $\begin{array}{l}\text { Y } \\
\text { es }\end{array}$ & $\begin{array}{l}\mathrm{N} \\
\mathrm{O}\end{array}$ & $\begin{array}{l}\text { Y } \\
\text { es }\end{array}$ & $\begin{array}{l}\mathrm{N} \\
\mathrm{O}\end{array}$ & $\begin{array}{l}\text { Y } \\
\text { es }\end{array}$ & $\begin{array}{l}\mathrm{N} \\
\mathrm{O}\end{array}$ & $\begin{array}{l}\text { Y } \\
\text { es }\end{array}$ & $\begin{array}{l}\mathrm{N} \\
\mathrm{O}\end{array}$ \\
\hline & & $\%$ & $\%$ & $\%$ & $\%$ & $\%$ & $\%$ & $\%$ & $\%$ & $\%$ & $\%$ & $\%$ & $\%$ \\
\hline 1 & MP & $\begin{array}{l}1 \\
0 \\
0\end{array}$ & 0 & $\begin{array}{l}9 \\
3\end{array}$ & 7 & $\begin{array}{c}10 \\
0\end{array}$ & 0 & $\begin{array}{c}10 \\
0\end{array}$ & 0 & 96 & 4 & 99 & 1 \\
\hline 2 & $\begin{array}{l}\text { PL } \\
S\end{array}$ & $\begin{array}{l}1 \\
0 \\
0\end{array}$ & 0 & $\begin{array}{l}9 \\
3\end{array}$ & 7 & $\begin{array}{c}10 \\
0\end{array}$ & 0 & 96 & 4 & 90 & $\begin{array}{l}1 \\
0\end{array}$ & 95 & 5 \\
\hline 3 & $\begin{array}{l}\text { PL } \\
B\end{array}$ & $\begin{array}{l}9 \\
8\end{array}$ & 2 & $\begin{array}{l}8 \\
4\end{array}$ & 16 & 87 & $\begin{array}{l}1 \\
3\end{array}$ & 89 & $\begin{array}{l}1 \\
1\end{array}$ & $\begin{array}{c}10 \\
0\end{array}$ & 0 & 92 & 8 \\
\hline 4 & BK & $\begin{array}{l}9 \\
5\end{array}$ & 5 & $\begin{array}{l}9 \\
5\end{array}$ & 5 & 87 & $\begin{array}{l}1 \\
3\end{array}$ & 91 & 9 & $\begin{array}{c}10 \\
0\end{array}$ & 0 & 93 & 7 \\
\hline 5 & $\mathrm{TP}$ & $\begin{array}{l}1 \\
0 \\
0\end{array}$ & 0 & $\begin{array}{l}9 \\
1\end{array}$ & 9 & 67 & $\begin{array}{l}3 \\
3\end{array}$ & 97 & 3 & $\begin{array}{c}10 \\
0\end{array}$ & 0 & 88 & $\begin{array}{l}1 \\
2\end{array}$ \\
\hline 6 & $\begin{array}{l}\text { PG } \\
\text { SD }\end{array}$ & $\begin{array}{l}9 \\
9\end{array}$ & 1 & $\begin{array}{l}8 \\
7\end{array}$ & 13 & $\begin{array}{c}10 \\
0\end{array}$ & 0 & 91 & 9 & 94 & 6 & 95 & 5 \\
\hline 7 & KP & $\begin{array}{l}9 \\
7\end{array}$ & 3 & $\begin{array}{l}8 \\
5\end{array}$ & 15 & $\begin{array}{c}10 \\
0\end{array}$ & 0 & 96 & 4 & $\begin{array}{c}10 \\
0\end{array}$ & 0 & 99 & 1 \\
\hline 8 & $\begin{array}{l}\text { PG } \\
\text { PA } \\
\text { UD }\end{array}$ & $\begin{array}{l}9 \\
2\end{array}$ & 8 & $\begin{array}{l}8 \\
4\end{array}$ & 16 & $\begin{array}{c}10 \\
0\end{array}$ & 0 & 95 & 5 & 93 & 7 & 96 & 4 \\
\hline 9 & $\mathrm{P}$ & $\begin{array}{l}1 \\
0 \\
0\end{array}$ & 0 & $\begin{array}{l}9 \\
3\end{array}$ & 7 & $\begin{array}{c}10 \\
0\end{array}$ & 0 & $\begin{array}{c}10 \\
0\end{array}$ & 0 & $\begin{array}{c}10 \\
0\end{array}$ & 0 & $\begin{array}{c}10 \\
0\end{array}$ & 0 \\
\hline & $\begin{array}{l}\mathrm{Me} \\
\text { an }\end{array}$ & $\begin{array}{l}9 \\
8\end{array}$ & $\begin{array}{l}2 \\
2 \\
5\end{array}$ & $\begin{array}{l}8 \\
9, \\
5 \\
7\end{array}$ & $\begin{array}{l}10 \\
4 \\
3\end{array}$ & $\begin{array}{c}93 \\
3 \\
3\end{array}$ & $\begin{array}{l}6 \\
6 \\
6 \\
7\end{array}$ & $\begin{array}{l}95 \\
1 \\
9\end{array}$ & $\begin{array}{l}4 \\
\text {, } \\
1\end{array}$ & $\begin{array}{l}97 \\
, 0 \\
4\end{array}$ & $\begin{array}{l}2 \\
9 \\
9 \\
6\end{array}$ & $\begin{array}{l}95 \\
1 \\
9\end{array}$ & $\begin{array}{l}4 \\
\dot{8} \\
1\end{array}$ \\
\hline
\end{tabular}

\section{Discussion}

From the result of the research, it can be concluded that the success of learning process in Faculty of Education Science of Universitas Negeri Yogyakarta was categorized as very good. It meant that learning process had been referred to the standard of Indonesian National Qualification Framework-based learning process.

However, the research result also showed that there was still item of statement which was not maximal. In the descriptor of understanding and study of knowledge and 
technology (in sub-variable of graduate's competence), it was found that all students keep up with recent technology development very well, looked for information concerning science, study knowledge, and wrote papers. This case needs attention from study program and faculty in order to create conducive academic culture. Therefore, students are able to improve their cognitive competence (knowledge). In affective competence mastery (attitude and mark), it was found that some students had not been honest in doing task and taking exam.The plagiarism was still found and some students arrived late. In addition, some students lacked of care about environment. It was found that they throw garbage in class room. In this case, the character building needs to be developed more intensively according to vision and mission of the university. In psychomotor competence mastery (skill), it was found that students' skill in implementing science and utilizing information needed to be optimized with various trainings, workshop, and seminar.

Evaluation of students' learning process with a set of knowledge, attitude, and skill matched the components of learning achievement. These components are employed as main material in arranging curriculum of study program. Therefore, the graduates will be able to shape themselves to be an intact and excellent individual which has strong and clean character [2]. He says that the results of learning process are output and outcome which cover soft skill and hard skill.The meanings of hard skill and soft skill are accommodated in learning process which is suitable with the dimension of cognitive process, affective process, and psychomotor process [3][2].

In sub-variable of curriculum development, it can be concluded that in general, the curriculum development had referred to Indonesian National Qualification Framework standard. The data or information which was given by the lecturers can be used to evaluate learning process [4]. They say that through evaluation process approach model, the lecturers who are involved in the research can give information concerning the implementation of curriculum in learning process in the class room.

The suggestions from the research are as follows: it needs to re-evaluate in certain period and mechanism of curriculum arrangement needs to be optimized by involving internal and externalstakeholders. In sub-variable of learning process, it can be concluded that preparation, execution, supervision, and final project guidance could be said to be suitable with the standard of Indonesian National Qualification Framework-based learning process. However, in learning evaluation aspect, lecturers' discipline in inputting score needed to be improved. In addition, the determination of final project guide lecturer needed to be adjusted according to their competence.

\section{CONCLUSION}

Based on the research result and discussion, it can be concluded that the success of Indonesian National Qualification Framework-based learning process in FIP UNY was categorized as very good $(92.35 \%)$. The success of learning process which was observed from graduate's competence aspect was categorized as very good (85.15\%). The success of learning process which was observed from curriculum development aspect was categorized as very good $(96.71 \%)$. The success of learning process which was observed from learning process aspectwas categorized as very good $(95.19 \%)$.

Based on the research result, the suggestions that the researcher can give are as follows:

a. The Faculty of Education Science should be able to maintain the quality of Indonesian National Qualification Framework-based learning process through intensive and continuous supervision and evaluation.

b. In giving lecture, FIP lecturers should improve lecture quality (material, strategy, and facility) constantly and enforce lecture rule.

c. Students of FIP should improve their skill of technology utilization. They should also improve their attitude so that they can be individuals with good character.

\section{REFERNCES}

[1] Peraturan Menteri Pendidikan dan Kebudayaan Republik Indonesia Nomor 73 Tahun 2013 tentang Penerapan Kerangka Kualifikasi Nasional Indonesia Bidang Pendidikan Tinggi.

[2] Tim Kurikulum dan Pembelajaran Dikti. Buku Kurikulum Pendidikan Tinggi. Jakarta: Direktorat Pembelajaran dan Kemahasiswaan, Direktorat Jenderal Pendidikan Tinggi, Kementerian Pendidikan dan Kebudayaan,2014.

[3] S. Eko Putro Widoyoko. Evaluasi Program Pembelajaran. Panduan Praktis bagi Pendidik dan Calon Pendidik. Yogyakarta: Pustaka Pelajar,2010.

[4] Arief Furchan, Muhaimin, \& Agus Maimun. Pengembangan Kurikulum Berbasis Kompetensi di Perguruan Tinggi Agama Islam. Yogyakarta: Pustaka Pelajar, 2005.

[5] Casmini. (2014). Evaluasi dan Peninjauan Kurikulum BKI Berbasis KKNI. Jurnal Hisbah, Vol. 11, No.1, Juni 2014.

[6] Djemari Mardapi. Evaluasi Penerapan Ujian Akhir Sekolah Dasar Berbasis Standar Nasional. Jurnal Penelitian dan Evaluasi Pendidikan. Journal.uny.ac.id,2013).

[7] Nana Sudjana. (2005). Penilaian Hasil Proses Belajar Mengajar. Bandung: PT. Remaja Rosdakarya.

[8] Nan Rahminawati, Agus Halimi, Imam Pamungkas (2015). Analisis dan Evaluasi terhadap Kurikulum Mata Kuliah Pendidikan Agama Islam (PAI) Universitas Islam Bandung Berbasis Kerangka Kualifikasi Nasional Indonesia (KKNI). Prosiding SnaPP2015 Sosial, Ekonomi, dan Humaniora. ISSN 2089-3590. EISSN 2303-2472. 
[9] Primardiana H.W.; Suyata; Sumarno. (2013). Model Evaluasi Pembelajaran Berbasis Kaizen di Sekolah Menengah Atas. Jurnal Penelitian dan Evaluasi Pendidikan. Tahun 17, Nomor 2, 2013.

[10] Purwanto. (2011). Evaluasi Hasil Belajar. Yogyakarta: Pustaka Pelajar.

[11] Reynolds, C.R.; Livingston, R.B.; Willson, V. (2010). Measurement and Assessment in Education. Second Edition. New Jersey: Pearson Education International.

[12] Wahyuningrum, dkk. (2015). Evaluasi Soal Ujian Akhir Semester Fakultas Ilmu Pendidikan, Universitas Negeri Yogyakarta. Laporan Penelitian. Yogyakarta: Fakultas Ilmu Pendidikan, Universitas Negeri Yogyakarta.

[13] Peraturan Presiden Nomor 8 Tahun 2012 tentang Kerangka Kualifikasi Nasional Indonesia.

[14] Peraturan Menteri Pendidikan dan Kebudayaan RI Nomor 49 Tahun 2014 tentang Standar Nasional Pendidikan, dan Standar Nasional Pengabdian kepada Masyarakat. 